\title{
Effects on maternal and foetal traits of feeding supplement to grazing pregnant ewes
}

\author{
P. Frutos ${ }^{1}$, O. Buratovich ${ }^{1}$, F. J. Giráldez 1 , A. R. Mantecón ${ }^{1}$ and I. A. Wright ${ }^{2}$ \\ ${ }^{1}$ Estación Agrícola Experimental, Consejo Superior de Investigaciones Científicas, Apartado 788, 24080-León, Spain \\ ${ }^{2}$ Macaulay Land Use Research Institute, Craigiebuckler, Aberdeen AB15 8QH
}

\begin{abstract}
Thirty single-bearing Merino ewes were used to examine the effect of feeding supplement, from 91 to 140 days of gestation, on changes in chemical composition of the ewes, on the relationships with live weight and body condition score and on the foetus. Eves grazed a perennial ryegrass pasture and were offered either no supplement or $500 \mathrm{~g}$ per head per day of a concentrate supplement from days 30 to 90 and (or) from days 91 to 140 of pregnancy. Maternal carcass and non-carcass components, uterine wall, foetus and placenta plus cotyledons were chemically analysed. Live weight (LW) and body condition score (BCS) on day 140 were both affected by supplementation during late pregnancy, mobilization of protein and fat being lower in animals receiving supplement. BCS accounted for more variation than LW in the carcass fat depot. Because this depot was the most important source of energy from days 91 to 140 of gestation, this suggests that BCS is a useful estimator of mobilization of maternal fat reserves during this stage of pregnancy. The ability to mobilize reserves and protect foetal growth by Merino ewes in southern Europe, where large fluctuations in grass growth rate exposes them to considerable undernutrition as pregnancy proceeds, was confirmed in this experiment. However, when the nutritional regime is extreme, supplementary feeding to the ewes is recommended, in order to make the whole system economically profitable.
\end{abstract}

Keywords: body condition, ewes, live weight, pregnancy, supplementary feeding.

\section{Introduction}

Sheep production systems in many parts of the world depend on pasture resources. In southern Europe, important seasonal variations occur in herbage availability with pasture yield being high in spring and greatly reduced in autumn/winter (Alonso, 1994). Changes in stocking rate could be used as a management strategy to overcome this variation. However, in practice, this is complicated to achieve and farmers often resort to feeding supplements.

Throughout the productive cycle, gestation is one of the most critical phases as it normally occurs in winter, when pasture growth is low. Undernutrition in pregnancy may influence foetal growth and development (Robinson, 1977 and 1990; McCrabb et al., 1992) although the ewe can maintain nutrient supplies to the foetus by mobilization of her own body reserves, buffering deleterious influences on foetal growth (Robinson, 1986; López and Robinson, 1994).
However, excessive mobilization of body reserves may lead to ewes being in very poor body condition and jeopardize reproductive potential in the following production cycle. While supplementation may overcome this problem, the amount of supplement offered needs to be optimized in order to ensure that the system is economically viable.

To apply information on nutritional requirements at critical times, nutritional adequacy needs to be estimated in the animal on the farm (Gunn, 1983). To this end, changes in live weight and body condition score have been widely used as estimators of the degree of mobilization of maternal reserves. Nevertheless, most studies relating live weight and body condition to body reserves have been carried out on non-pregnant animals. Also, it must be taken into account that relationships between live weight, body condition score and body reserves derived from studies in one breed cannot be applied with confidence to others. In addition, mobilizations of body reserves might depend on the adaptation of the 
breed to the environment in which it is kept (Frutos et al., 1997).

The present experiment was carried out to examine the effect of feeding supplement to grazing Merino sheep in southern Europe on changes in chemical composition of the ewes, from 91 to 140 days of gestation, taking into account their previous nutritional status. The relationship between live weight and body condition score and the effect on the foetus over the same period were also studied.

\section{Material and methods}

\section{Experimental design}

This study was conducted using 30 single-bearing Merino ewes, ranging in age from 3 to 4 years, in live weight (LW) from 44.8 to $57.6 \mathrm{~kg}$ and in body condition score (BCS) from 1.25 to 3.25 , at the beginning of the experiment. The animals belonged to the flock of the research farm of the Spanish Council for Scientific Research (Consejo Superior de Investigaciones Científicas), León, Spain.

Oestrous cycles were synchronized in September using intravaginal sponges containing $60 \mathrm{mg}$ of medroxi-progesterone acetate (SINCRO-GEST ${ }^{\circledR}$ ), and all ewes were mated 2 days after sponge removal (day 0). One month after mating (day 30), pregnancy was confirmed by ultrasonic scanning and animals were allocated to six groups of five animals, as follows. Groups of animals slaughtered on day 90 : group G - grazed from day 30 to 90 ; group $S-$ grazed + concentrate supplement from day 30 to 90 . Groups of animals slaughtered on day 140: group GG - grazed from day 30 to 140; group GS grazed from day 30 to 90 and grazed +concentrate supplement from day 91 to 140; group SG - grazed + concentrate supplement from day 30 to 90 and only grazed from day 91 to 140; group SS - grazed + concentrate supplement from day 30 to 140 .

Table 1 Chemical composition ( $g / k g$ dry matter) of pastures $A$ and $B$ on days 30,90 and 140 of the experiment

\begin{tabular}{llll}
\hline & \multicolumn{3}{c}{ Day of experiment } \\
\cline { 2 - 4 } & 30 & 90 & 140 \\
\hline Pasture A & & & \\
$\quad$ Organic matter & 900 & 856 & 826 \\
$\quad$ Crude protein & 226 & 193 & 186 \\
$\quad$ Neutral-detergent fibre & 361 & 447 & 482 \\
Pasture B & & & \\
Organic matter & 884 & 830 & 799 \\
$\quad$ Crude protein & 226 & 209 & 187 \\
$\quad$ Neutral-detergent fibre & 367 & 457 & 490 \\
\hline \hline
\end{tabular}

A perennial ryegrass dominant pasture containing Lolium perenne, Festuca pratensis and Trifolium repens of about 1 ha, was subdivided into two plots, $\mathrm{A}$ and B. Groups G, GG and GS grazed on plot A and groups S, SS and SG on plot B, from day 30 to 90 . On day 90 , groups GS and SG were switched over from one plot to the other. Chemical composition of pastures $\mathrm{A}$ and $\mathrm{B}$ on days 30,90 and 140 are given in Table 1.

Supplemented animals were offered as a group $500 \mathrm{~g}$ per head, once daily, a concentrate supplement formulated with barley $(850 \mathrm{~g} / \mathrm{kg})$, soya-bean meal $(120 \mathrm{~g} / \mathrm{kg})$ and a mineral-vitamin mixture $(30 \mathrm{~g} / \mathrm{kg})$, its composition being: $934 \mathrm{~g}$ dry matter (DM) and $134 \mathrm{~g}$ crude protein (CP) per $\mathrm{kg}$.

\section{Slaughter}

After a fast of $24 \mathrm{~h}$ the ewes were shorn and then slaughtered by exsanguination from the jugular vein, after being injected intravenously with $1 \mathrm{ml}$ xilocine (Rompun ${ }^{\circledR}$ ). Blood and wool collected were not analysed but were assumed to have the chemical composition described by the Agricultural Research Council (1980). The procedure at slaughter (Frutos et al., 1997) was designed to partition each body into carcass and non-carcass components. The gastrointestinal tract was emptied and its contents weighed to obtain empty body weight (EBW). The fatty tissue surrounding the alimentary tract (omental and mesenteric fat) was removed, along with any associated connective tissue, and weighed. Kidney and pelvic fat was also weighed after removal of the kidneys.

Following the procedure described by McCrabb et al. (1991), the uterus was tied off as close as possible to the cervix with cotton thread. After weighing the gravid uterus, an incision was made along the greater curvature of the pregnant horn and the foetus exposed. The umbilical cord was tied off with cotton thread and severed. The foetus was immediately removed, killed with a lethal dose of xilocine (Rompun $^{\circledR}$ ) and weighed. The foetal membranes were dissected from the cotyledons and all placentomes, including the foetal cotyledons and maternal caruncle, were then dissected from the uterine wall, and the total weight was recorded.

Maternal carcass and non-carcass components, uterine wall, foetus and placenta plus cotyledons were stored in separate polyethylene bags at $-20^{\circ} \mathrm{C}$ until preparation for analysis. After thawing, they were cut into pieces and minced using a blender fitted with an end plate containing holes of $7 \mathrm{~mm}$ diameter. Then they were minced again through another plate with $4-\mathrm{mm}$ holes. The mince was then mixed thoroughly and subsamples freeze dried. 
All samples from slaughter, after having been freeze dried to determine water content, were analysed for $\mathrm{CP}$ and ash by Association of Official Analytical Chemists (AOAC, 1990) procedure. Fat content was estimated by difference.

Measurements and analyses

LW and BCS (Russel et al., 1969) were recorded once per week throughout the experiment.

Sward surface height was measured once per week in 40 randomly chosen locations per plot using a 'sward stick' (Barthram, 1986).

Herbage intake by grazed ewes was estimated according to the equation developed by Linehan et al. (1947):

$C=\left(M-M^{f}\right)\left(\log \left(M+\Delta M^{e}\right)-\log M f\right) /\left(\log M-\log M^{f}\right)$

where, $C=$ herbage consumed $(\mathrm{kg}) ; M=$ herbage mass at the start of a grazed period $(\mathrm{kg} / \mathrm{ha}) ; M^{f}=$ residual herbage at the end of a grazed period $(\mathrm{kg} /$ ha); $\Delta M^{e}=$ undisturbed herbage accumulation in exclosure during a grazed period $(\mathrm{kg} / \mathrm{ha})$.

Herbage mass (total mass of herbage per unit area of ground) was estimated every 2 weeks throughout the experiment by hand cutting, as close as possible to ground level, two quadrats of $0.25 \mathrm{~m}^{2}$ in each plot.

Undisturbed herbage accumulation was estimated every 2 weeks in three exclosure cages of $1 \mathrm{~m}^{2}$ in each pasture. These cages were moved to new randomly chosen positions after each sampling.

Herbage samples from quadrats were dried in an oven at $60^{\circ} \mathrm{C}$ and then analysed for $\mathrm{CP}$ and ash (AOAC, 1990) and for neutral-detergent fibre (Goering and Van Soest, 1970).

\section{Statistical analysis}

The experiment was analysed using analysis of variance with a factorial treatment structure.
Regression analysis was used to evaluate relationships between BCS, LW and several body components. All data were analysed using the Complete Statistical System (Statsoft, 1991).

For data relative to groups GG, GS, SG and SS, analysis of variance was used to study the effect of the level of supplementation during the second half of gestation (from day 91 to day 140 of the experiment), taking into account the effect of the level of supplementation during the first half (from day 30 to day 90 of the experiment). In order to remove the effect of $\mathrm{LW}$ at the beginning of the experiment, this variable was included in the analysis of variance as a covariate. Likewise, for data on conceptus components at day 140, the sex of the foetus was included in the analysis of variance as a covariate.

For data on sward height and disappearance (= intake) in each period, level of supplementation was considered as a main effect and cuts as replicates.

\section{Results}

Table 2 shows mean sward height and intake of grass by supplemented and non-supplemented ewes for the two experimental periods.

Sward height showed a marked decrease in the second period. There were no significant differences in the herbage disappearance due to the level of supplementation ( 0 v. $500 \mathrm{~g}$ per ewe per day) in either period $(P>0.05)$.

As expected (Orr and Treacher, 1984), supplementation with $500 \mathrm{~g}$ concentrate per animal per day did not suppress forage intake, because herbage allowance was low and probably limited intake (see in Table 2 the low values of sward height).

Changes in LW and BCS of the sheep from days 30 to 90 and 91 to 140 of the experiment are presented in

Table 2 Mean sward height and herbage disappearance for supplemented and non-supplemented groups for the two experimental periods (days 30 to 90 and days 91 to 140)

\begin{tabular}{|c|c|c|c|c|c|}
\hline \multirow[b]{2}{*}{ Pasture } & \multicolumn{2}{|c|}{ Days 30-90 } & \multicolumn{2}{|c|}{ Days $91-140$} & \multirow[b]{3}{*}{ Pooled s.e } \\
\hline & A & B & A & B & \\
\hline Experimental groupt & G, GG, GS & S, SG, SS & GG, SG & SS, GS & \\
\hline Sward height $(\mathrm{cm})$ & $3 \cdot 44$ & $5 \cdot 04$ & $1 \cdot 34$ & $1 \cdot 62$ & 0.794 \\
\hline Herbage disappearance (kg DM per ewe per day) & 0.59 & $0 \cdot 60$ & 0.57 & 0.56 & 0.078 \\
\hline
\end{tabular}

+ Experimental groups: G - grazing from day 30 to 90; $\mathrm{S}$ - grazing + supplement from day 30 to 90 ; GG - grazing from day 30 to 140; GS - grazing from day 30 to 90 and grazing + supplement from day 91 to 140; SG - grazing + concentrate from day 30 to 90 and only grazing from day 91 to 140; SS - grazing + concentrate from day 30 to 140 . 


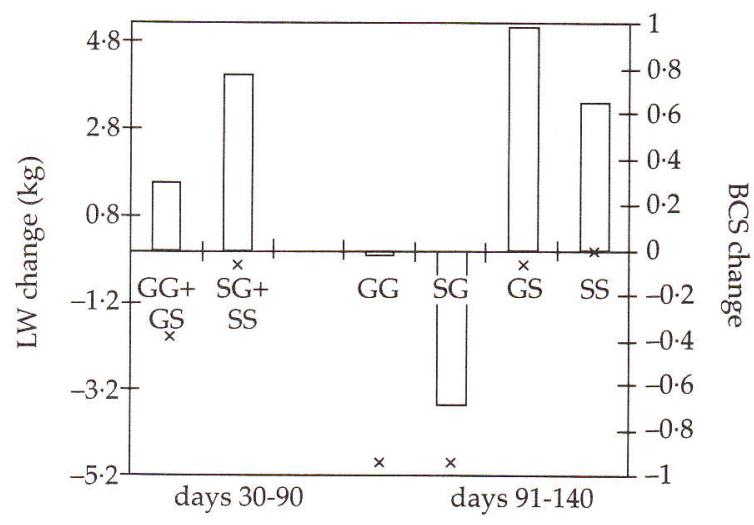

Figure 1 Change in live weight (LW) ( $\square$ ) and body condition score (BCS) $(\boldsymbol{X})$ from days 30 to 90 and 91 to 140 of the experiment for the ewes slaughtered on day 140 .

Figure 1. On day 30, ewe LW averaged $51.3 \mathrm{~kg}$ (residual s.d. $=5.42$ ) and BCS 2.7 (residual s.d. $=$ $0 \cdot 42)$.

LW and BCS on days 90 and 140 were not affected by supplementation between days 30 and 90 . However LW and BCS on day 140 were significantly affected by supplementation during the last period of gestation (from day 91 to day 140) $(P<0 \cdot 05)$.
Supplemented animals had higher BCS and LW than those which had not been supplemented.

Animals receiving $500 \mathrm{~g}$ supplement per day over this period (groups GS and SS) proportionately increased LW by 1.08 , while animals from groups GG and SG proportionately decreased LW by 0.97 , despite the increase of the weight of the conceptus. There were no interactions between supplementation and period.

BCS and LW on day 140 of pregnancy were significantly correlated $(r=0.70 ; P<0.05)$. Body condition score and maternal live weight (LW corrected for the conceptus weight) on day 140, showed a correlation coefficient of 0.74 . From the regression analysis, the change of LW per unit change in BCS was less during the second period than during the first period $(b=7.9$, s.e. $=2.18 v \cdot b=$ $5 \cdot 0$, s.e. $=1 \cdot 36)$.

Empty body chemical composition on day 140 and changes in carcass and non-carcass chemical composition of the ewes from day 91 to 140 of the experiment are given in Table 3 . EBW represented 0.77 (residual s.d. $=0.027$ ) of the LW. Supplementation during the last period of gestation had a significant effect on all the major constituents of the maternal body $(P<0.05)$. There was a significant effect of supplementation from days 30 to

Table 3 Empty body chemical composition on day 140 and changes in carcass and non-carcass chemical composition of the ewes over the last period of pregnancy (91 to 140 days)

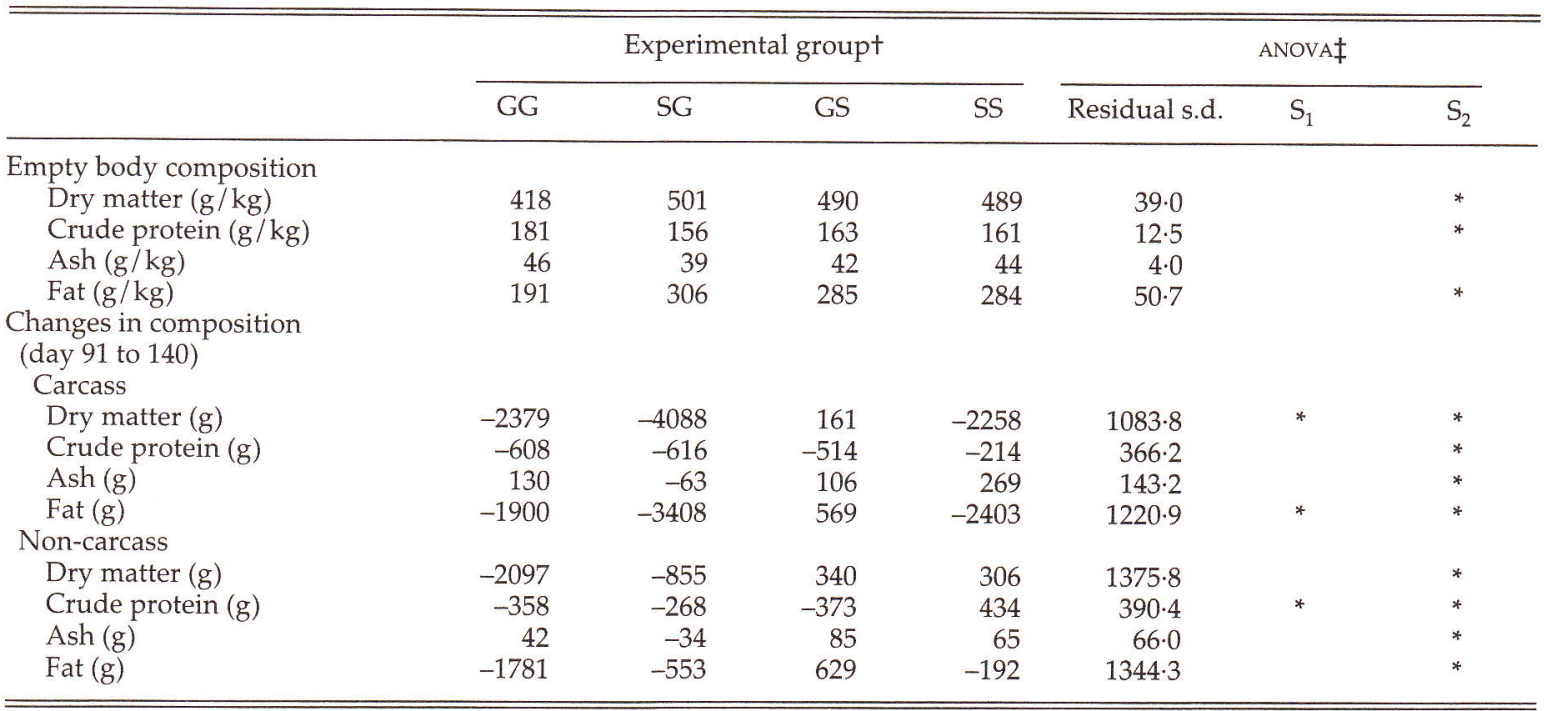

+ Experimental group: see Table 2.

$\ddagger \mathrm{S}_{1}=$ effect of supplementation from days 30 to $90 ; S_{2}=$ effect of supplementation from days 91 to $140 ; S_{1} S_{2}=$ interaction $\mathrm{S}_{1} \times \mathrm{S}_{2}$ (there were no significant interaction effects $(P>0 \cdot 05)$ ). 
90 on changes in carcass DM and fat and in noncarcass protein contents from days 91 to 140 . However, there were no significant interactions.

There was a greater loss of empty body protein from the bodies of non-supplemented animals from days 91 to 140 . Only animals in group SS showed an increase of protein in the non-carcass. Fat mobilization was lower in animals that received supplement. Only group GS showed a positive accretion of fat. Total internal fat (kidney and pelvic depot plus omental depot plus mesenteric depot) weight was significantly higher at day 140 in animals that had received supplementation $(P<0.05)$, absolute values being $2351 \mathrm{~g}$ in group GG v. $5290 \mathrm{~g}$ in group SS (residual s.d. $=1663 \cdot 4$ ). The mesenteric depot accounted for most of this difference and was significantly lower in non-supplemented ewes $(P<0.05)$.

On day 90, protein content was not significantly correlated with either LW or BSC $(P>0.05)$. The same lack of correlation was observed between those two variables and the non-carcass fat depot. Body condition score $\left(R^{2}=0.70\right)$ and LW $\left(R^{2}=0.64\right)$ accounted for most of the variation in carcass fat.

Similar $R^{2}$ values were observed when either BCS $(0.55)$ or LW $(0.58)$ were used to predict total fat content of ewes slaughtered on day 140. Inclusion of both variables together (BCS and LW) significantly improved the accuracy of its estimation $\left(R^{2}=0 \cdot 70\right)$. This was also the case for carcass and non-carcass depots separately. On day 140, LW was a better predictor of body protein $\left(R^{2}=0.79\right)$ than BCS $\left(R^{2}=\right.$ $0 \cdot 35)$ and inclusion of both fitted terms together did not improve the estimation.

Table 4 shows chemical composition of the uterine wall, foetus and placenta plus cotyledons on day 140 of pregnancy. Accretion of protein, fat and ash in the uterine wall (mean weight $=691$ g; residual s.d. 99.3) were higher in sheep supplemented from day 90 to day 140 of pregnancy but there was neither a significant effect of supplementation in the previous phase nor any significant interaction. Protein was the component that showed the highest rates of accretion and its variation accounted for proportionately 0.8 of the variation in the DM weight of the uterus.

The foetus weighed more on day 140 from conception when the mother had received supplement from days 91 to 140, with values of $3988 \mathrm{~g}, 4482 \mathrm{~g}, 3715 \mathrm{~g}$ and $4179 \mathrm{~g}$ for groups GG, GS, SG and SS, respectively (residual s.d. = 390.9; $P<0.05$ ). Nevertheless, composition of the foetuses was not significantly affected by the level of supplementation (see Table 4). Foetus weight increased during this period, although increases of DM accounted for less than 0.21 of this increment. Protein retention accounted for most of the DM accretion.

Placenta and cotyledons weighed on average $695 \mathrm{~g}$ (residual s.d. $=166.2$ ), chemical composition being similar in the four groups. Fat represented a very low proportion of the DM, the principal component being protein.

Table 4 Chemical composition of the uterine wall, foetus and placenta plus cotyledons on day 140 of pregnancy

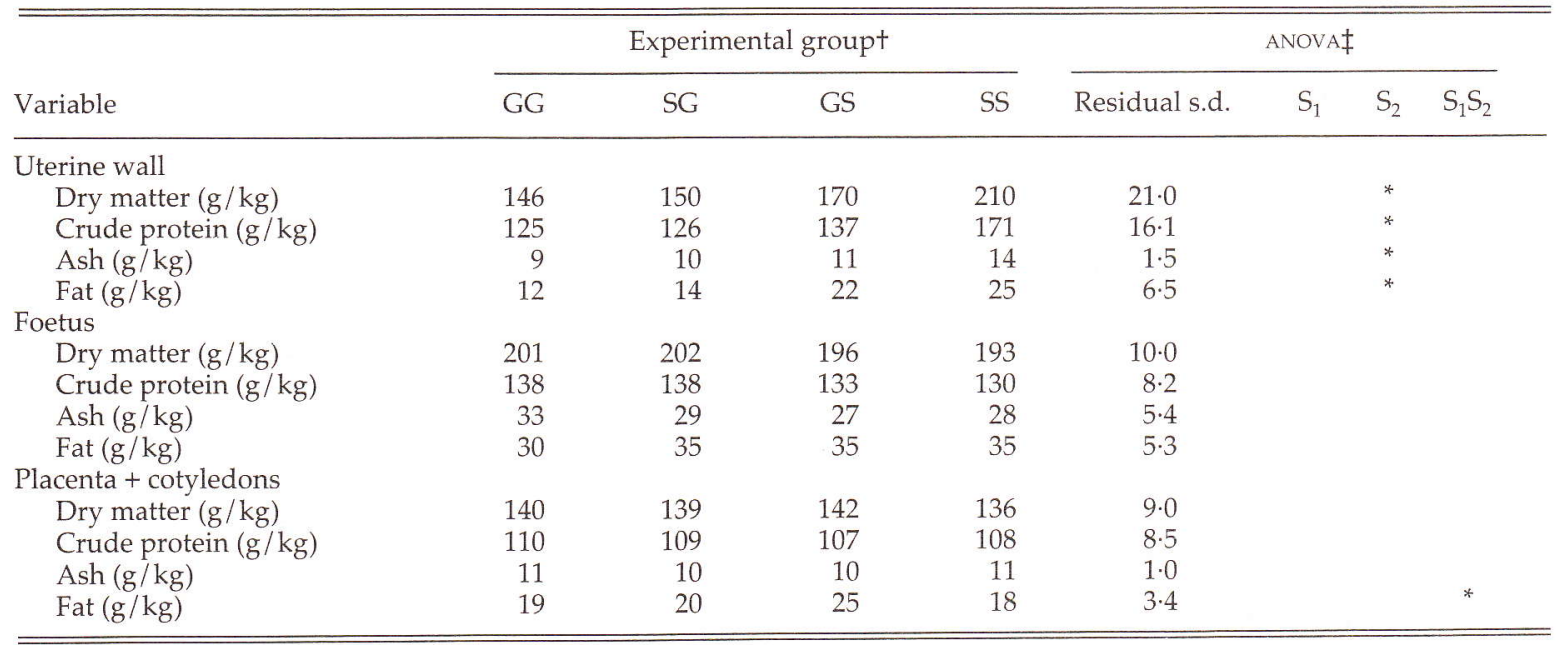

† See Table 2. $\ddagger$ See Table 3 . 


\section{Discussion}

LW and BCS on day 140 were both affected by supplementation during late pregnancy, being significantly higher in supplemented animals. Within these supplemented ewes, those from group GS gained proportionally 0.23 more weight than animals from group SS. This might indicate that homeostatic mechanisms partition dietary nutrients toward replenishment of maternal reserves rather than foetal growth (Rattray et al., 1980). However, no differences in foetus weight or body composition were found in this experiment between groups GS and SS, which may suggest that the differences in changes of LW could be due to differences in digestive contents or in maintenance requirements and efficiency of utilization caused by previous nutritive status (Allden, 1970). However, individual levels of herbage intake were not estimated, and because it is known that body condition can affect intake, it is likely that the GS sheep had higher herbage intakes.

On the other hand, ewes from group GG experienced lower losses of LW than ewes from group SG during the last period of the gestation (days 91 to 140 , see Figure 1). It has been widely reported that fat animals can mobilize their reserves much more easily than thin animals (Rattray et al., 1980; McCrabb et al., 1990). Thus, group SG probably had a greater ability to mobilize body reserves as a consequence of the fat accumulation in the previous period (days 30 to 90 ).

Mobilization of protein and fat reserves was lower in animals receiving supplement. Comparisons within supplemented and non-supplemented groups showed the same trend as data concerning changes of LW mentioned above. Thus, for example, all ewes mobilized fat depots except those in group GS, which had a positive accretion of fat. Fat mobilization from internal depots was lower than from carcass depots, which follows the general principle that breeds noted for meat production, such as the Merino, tend to deposit more fat in the carcass depot, in contrast to breeds noted for milk production which tend to deposit more fat in internal depots (Taylor et al., 1989; Frutos et al., 1997). In addition, the proportion of fat mobilized from different depots depends on degree of fatness as well as breed (Wright and Russel, 1984a). There were significant differences in mobilization from internal depots, the mesenteric depot being the one that accounted for most of this mobilization.

Loss of protein may not only imply a degree of protein deficiency directly detrimental to the normal protein metabolism of the body but it may also indicate bone matrix erosion that generally accompanies protein deficiency (Robinson, 1986).
Changes in LW and in LW corrected for the conceptus weight per unit change in BCS were lower during the second period (from day 91 to day 140). This variation is probably accounted for by simultaneous increases in the weight of mammary gland $(491 \mathrm{~g}$, residual s.d. $=183.8)$ and uterus $(422 \mathrm{~g}$, residual s.d. $=98.8$ ) and losses of the body reserves during late pregnancy.

Relationships of LW and BCS with maternal fat and protein contents were examined as predictors of maternal reserves, which in practice can allow application of information concerning critical phases of pregnancy and nutritional requirements. However, the danger of relying on BCS or weightgain targets during pregnancy as indices of adequate nutrition must not be forgotten (Robinson, 1986). In this experiment, it was found that, on day 140 of pregnancy, similar $R^{2}$ values were observed when either BCS or LW were used to predict the total fat content. The accuracy of the estimation improved when both fitted terms were included together. The same applied to the prediction of carcass and noncarcass fat depots separately. LW was by far the best predictor of protein content as has been reported previously (Wright and Russel, 1984b; Frutos et al., 1997). On day 90 of pregnancy, neither LW nor BCS were significantly correlated with either protein or non-carcass fat content. However, the smaller number of animals slaughtered on day 90 of pregnancy could have affected the reliability of the relationship. BCS accounted for most variation in the carcass fat depot. Because this depot was the most important source of energy in pregnant ewes (at least of the Merino breed) from days 91 to 140 of gestation, this suggests that BCS is a useful estimator of mobilization of maternal fat reserves over the last period of the pregnancy. LW, on the other hand, could be a better estimator of protein mobilization.

Nutrients for conceptus growth may be directly supplied from products of digestion or through the mobilization of components of maternal body tissues, so buffering deleterious influences on foetal growth (López and Robinson, 1994; Robinson, 1986). It is assumed that maternal supply of nutrients to the pregnant uterus has an important direct influence on umbilical nutrient uptake and foetal growth (Bell, 1984). In this experiment, the uterine wall showed a significantly higher deposition of fat and protein in supplemented ewes. This had a direct influence on the weight of foetuses on day 140, which was significantly higher in those from supplemented mothers. However, as can be observed in Table 4, this was not reflected in the chemical composition of either the foetus or the placenta and cotyledons, which suggests differences only in the foetal growth rate. 
Maternal capacity for accommodating nutritional deficiencies during pregnancy by depletion and subsequent repletion of her body reserves has been widely reported. The current results extend previous findings to Merino ewes in southern Europe where pastures are characterized by large fluctuations in growth rate during different seasons, such that ewes may be exposed to considerable under-nutrition as pregnancy proceeds (normally during winter). In this experiment we confirmed the ability of the mother to mobilize reserves and protect foetal growth during periods of maternal under-nutrition. However, when the nutritional regime is extreme, this mobilization may not be sufficient and the birth weight of the lambs may be reduced and, perhaps, their subsequent development may be affected. In addition, high mobilizations of body reserves in late pregnancy may reduce the reproductive potential of ewes in the following year (Brusa et al., 1997). Overall, this suggests that providing supplementary feeding to the ewes over the last period of pregnancy is desirable in order to make the whole system economically profitable, at least under the conditions in this experiment.

\section{Acknowledgement}

This work was supported by the EU Commission (Project AIR CT 92-0646) and the Junta de Castilla y León (Project CSI 3/96). The authors thank $\mathrm{Mr} J$. López for the management of the animals and data collection.

\section{References}

Agricultural Research Council. 1980. The nutrient requirements of ruminant livestock. Technical review by an Agricultural Research Council working party. $\mathrm{CAB}$ International, Wallingford, UK.

Allden, W. G. 1970. The effects of nutritional deprivation on the subsequent productivity of sheep and cattle. Nutrition Abstracts and Reviews 40: 1167-1184.

Alonso, I. 1994. Estudio ecológico y valoración de un sistema pastoral de la montaña de León. Tesis doctoral, Universidad de León.

Association of Official Analytical Chemists. 1990. Official methods of analysis of the Association of Official Analytical Chemists, 15th edition. Association of Official Analytical Chemists, Washington, DC.

Barthram, T. 1986. Experimental techniques: the HFRO sward stick. HFRO biennial report 1984-85, pp. 29-30.

Bell, A. W. 1984. Factors controlling placental and foetal growth and their effects on future production. In Reproduction in sheep (ed. D. R. Lindsay and D. T. Pearce), pp. 144-152. Cambridge University Press, London.

Brusa, C. M., Giráldez, F. J., Buratovich, O. F. and Mantecón, A. R. 1997. Effect of long-term supplementation on animal performance of grazed ewes. Proceedings of the British Society of Animal Science, 1997, pp. 157 (abstr.).

Frutos, P., Mantecón, A. R. and Giráldez, F. J. 1997. Relationship of body condition score and live weight with body composition in mature Churra ewes. Animal Science 64: 447-452.

Goering, M. K. and Van Soest, P. J. 1970. Forage fiber analysis (apparatus, reagents, procedures and some applications). Agricultural handbook no. 379. Agricultural Research Service, USDA, Washington, USA.

Gunn, R. G. 1983. The influence of nutrition on the reproductive performance of ewes. In Sheep production (ed. W. Haresign), pp. 99-110. Butterworths, London.

Linehan, P. A., Lowe, J. and Steward, R. H. 1947. The output of pasture and its measurement. Part II. Journal of the British Grassland Society 2: 145-168.

López, S. and Robinson, J. J. 1994. Nutrición y gestación en el ganado ovino. Investigación Agraria: Producción y Sanidad Animales 9: 189-219.

McCrabb, G. J., Egan, A. R. and Hosking, B. J. 1990. The effect of maternal body condition on glucose metabolism and foetal growth during late pregnancy. Proceedings of the Australian Society of Animal Production 18: 519.

McCrabb, G. J., Egan, A. R. and Hosking, B. J. 1991 Maternal undernutrition during mid-pregnancy in sheep: placental size and its relationship to calcium transfer during late pregnancy. British Journal of Nutrition 65: 157-168.

McCrabb, G. J., Hosking, B. J. and Egan, A. R. 1992. Changes in the maternal body and feto-placental growth following various lengths of feed restriction during midpregnancy in sheep. Australian Journal of Agricultural Research 43: 1429-1440.

Orr, R. J. and Treacher, T. T. 1984. The effect of concentrate level on the intake of hays by ewes in late pregnancy. Animal Production 39: 89-98.

Rattray, P. V., Trigg, T. E. and Ulrich, C. F. 1980. Energy exchanges in twin-pregnant ewes. In Energy metabolism (ed. L. E. Mount), pp. 325-328. Butterworths, London.

Robinson, J. J. 1977. The influence of maternal nutrition on ovine foetal growth. Proceedings of the Nutrition Society 36: 9-16.

Robinson, J. J. 1986. Changes in body composition during pregnancy and lactation. Proceedings of the Nutrition Society 45: 71-80.

Robinson, J. J. 1990. Nutrition in the reproduction of farm animals. Nutrition Research Reviews 3: 253-276.

Russel, A. J. F., Doney, J. M. and Gunn, R. G. 1969 Subjective assessment of body fat in live sheep. Journal of Agricultural Science, Cambridge 72: 451-454.

Statsoft. 1991. Complete statistical system. Statsoft, Inc., Tusla, USA.

Taylor, St C. S., Murray, J. I. and Thonney, M. L. 1989. Breed and sex differences among equally mature sheep and goats. Animal Production 49: 385-409.

Wright, I. A. and Russel, A. J. F. 1984a. Partition of fat, body composition and body condition in mature cows. Animal Production 38: 23-32.

Wright, I. A. and Russel, A. J. F. 1984b. Estimation in vivo of the chemical composition of bodies of mature cows. Animal Production 38: 33-44.

(Received 9 October 1997-Accepted 31 December 1997) 